\title{
PENGAMBILAN KEPUTUSAN INVESTASI GENERASI Y TERHADAP PRODUK TABUNGAN EMAS DI PEGADAIAN SYARIAH CABANG BABAKAN, KOTA SURABAYA
}

Kholishudin

STAI Al Azhar Menganti, Gresik, Indonesia

kholishudinmuhammad@gmail.com

\begin{abstract}
The article entitled Generation Y Investment Decision Making on Gold Savings Products at the Babakan Sharia Branch, Surabaya City, answers the question of how Babakan Sharia Pawnshop strategy targets Generation $Y$ to invest in gold savings products and how generation $Y$ makes investment decisions on savings products gold Babakan Syariah Pegadaian. The results showed that I) the strategy owned by Pawnshop Syariah Babakan in attracting Generation $Y$ is by doing a lot of promos on social media, Instagram, Facebook and electronic media such as advertisements on television. The promo always includes attractive discounts and prizes that make customers want to invest in gold savings. 2) the decision making by generation $Y$ is based on several factors, namely economic, social and psychological. In this condition, there are several $Y$ generation informants who choose gold savings
\end{abstract}

Keywords: Strategy, Decision Making, Gold Savings.

Abstrak: Artikel yang berjudul Pengambilan Keputusan Investasi Generasi Y Terhadap Produk Tabungan Emas Di Pegadaian Syariah Cabang Babakan, Kota Surabaya, menjawab persoalan bagaimana strategi Pegadaian Syariah Babakan dalam membidik Generasi Y untuk berinvestasi produk tabungan emas serta bagaimana pengambilan keputusan investasi yang dilakukan oleh generasi $Y$ terhadap produk tabungan emas Pegadaian Syariah Babakan. Hasil penelitian menunjukkan bahwa I) strategi yang dimiliki oleh Pegadaian Syariah Babakan dalam menarik Generasi Y yakni dengan cara banyak melakukan promo di media social instagram, facebook serta media eletronik seperti iklan di televisi. Dalam promo tersebut selalu disertakan diskon dan hadiah menarik sehingga membuat nasabah ingin melakukan investasi tabungan emas. 2) pengambilan keputusan yang dilakukan oleh generasi $Y$ didasari oleh beberapa factor yakni ekonomi, social dan psikologis. Pada kondisi tersebut terdapat beberapa informan generasi $Y$ ada yang memilih tabungan emas serta ada yang tidak memilih tabungan emas karena mereka menganggap bahwa emas itu keuntungan yang didapatkan relatif lama sedangkan karakteristik generasi Y itu ingin keuntungan yang besar dengan waktu yang tidak terlalu lama.

Kata Kunci: Strategi, Pengambilan Keputusan, Tabungan Emas. 

Kholishudin

\section{A. Pendahuluan}

Setiap tindakan manusia sehari-hari selalu didasari oleh keputusan yang diambil. Mulai aktivitas individual hingga aktivitas dalam perekonomian, itu semuanya didasari oleh keputusan yang telah ditetapkan sebelumnya. Namun demikian, karena keputusankeputusan tersebut telah rutin diambil membuat individu untuk tidak lagi berfikir lama dalam menetapkan keputusan tersebut. Setiap tindakan seolah-olah dilakukan begitu saja tanpa adanya pertimbangan. Di luar tindakan rutin tersebut, permasalahan yang perlu dipertimbangkan matang-matang selema mengambil keputusan. Hal ini dikarenakan keputusan yang dibuat harus didasari pada berbagai pertimbangan yang matang dari berbagai kemungkinan yang ada.

Keputusan untuk memilih ini tidak selalu mudah, terutama karena kita memiliki keterbatasan. Apabila dengan keterbatasan tersebut dipaksa untuk mendapatkan sesuatu yang sangat ideal, maka tidak jarang keputusan tersebut menjadi salah. Akibatnya harus menanggung risiko dalam memilih pilihan yang kurang tepat sehingga dapat merugikan. Dalam pengambilan keputusan ini juga diperlukan ketelitian, termasuk dalam memilih instrumen investasi yang akan diambil oleh seseorang, karena pada hakikatnya investasi merupakan penempatan sejumlah dana pada saat ini dengan harapan untuk memperoleh keuntungan di masa mendatang (Abdul Halim, 2005:76).

Investasi selalu memiliki dua sisi yaitu return dan risiko. Dalam berinvestasi, berlaku hukum bahwa semakin tinggi return yang ditawarkan maka semakin tinggi pula risiko yang harus ditanggung oleh investor (EduardusTendelin, 200I: 43). Instrumen investasi dengan return yang tinggi tidak selalu menarik untuk semua investor, demikian juga sebaliknya instrumen investasi yang memberikan return rendah dan stabil belum tentu menjadi pilihan investor. Apabila investor tidak cermat saat berinvestasi maka investor akan mengalami kerugian bahkan lebih dari itu yakni kehilangan seluruh modalnya.

Banyak calon investor yang ingin melakukan investasi, namun tersedianya berbagai bentuk dan jenis instrumen investasi yang ada menjadi salah satu factor penyebab investor Volume. 8/No. 2/Juli 2020 Al-Iqtishod |9I 
Pengambilan Keputusan Investasi ...

tidak dapat memutuskan secara langsung instrumen investasi yang akan dipilihnya. Tujuan umum dari investasi adalah untuk menciptakan uang dan meningkatkan nilai uang serta kekayaan dari investor baik untuk masa sekarang maupun masa yang akan datang. Secara spesifik, para investor dalam melakukan investasi memiliki tujuan dan latar belakang yang berbeda-beda. Hal ini disebabkan karena setiap investor memiliki karakter yang unik dan kemampuan finansial yang berbeda pula. Inilah yang menjadi penting dan yang selalu di pertimbangkan pada saat investor memutuskan untuk mengambil salah satu bentuk instrumen investasi.

Ada banyak instrumen investasi dimana investor dapat menginvestasikan dana mereka yang berlebih. Emas selalu menjadi investasi yang terpercaya yang menawarkan return keuangan kepada investor. Ada manfaat signifikan dalam investasi emas yang membantu memenuhi tujuan investor. Ketika investor berinvestasi emas, itu berarti mereka telah berinvestasi dalama setriil. Nilai emas yang stabil terhadap kondisi makro yang sedang terjadi seperti pada masa krisis inflasi atau perang yang mengakibatkan emas dianggap sebagai tempat yang palilng aman untuk menyimpan uang pada kondisi yang penuh dengan ketidakpastian.

Dalam berinvestasi tentunya didasari oleh perilaku konsumen yang sangat dipengaruhi oleh keadaan dan situasi lapisan masyarakat dimana ia dilahirkan dan berkembang. Ini berarti konsumen berasal dari lapisan masyarakat atau lingkungan yang berbeda akan mempunyai penilaian, kebutuhan, pendapat, sikap, danselera yang berbeda-beda, sehingga pengambilan keputusan dalam tahap pembelian akan dipengaruh ioleh beberapa faktor. Faktor-faktor $\mathrm{t}$ ersebut dapat berasal dari kebudayaan dimana budaya juga merupakan penentu keinginan dan perilaku yang paling mendasar. Faktor berikutnya yakni tentang sosial. Pada dasarnya perilaku seorang konsumen dipengaruhi oleh faktor-faktor social seperti kelompok acuan serta status social (Henry Assel, 200I:30). Pemahaman terhadap perilaku konsumen ini bukanlah suatu hal yang mudah untuk dilakukan, karena terdapat banyak faktor yang saling berkesinambungan satu sama yang lainnya, sehingga pendekatan pemasaran yang dilakukan oleh suatu perusahaan harus benar-benar dirancang sebaik 
mungkin dengan memperhatikan faktor-faktor tersebut (Wiku, 2011:86). Dengan adanya faktor-faktor tersebut dapat mempengaruhi perilaku konsumen untuk mengambil keputusan berinvestasi.

Saat ini instrumen investasi yang ditawarkan di Indonesia sudah mulai banyak pilihan dan sudah diawasi langsung oleh (OJK) Otoritas Jasa Keuangan. Berkaitan dengan pilihanpilihan dalam berinvestasi yang ditinjau dari segi bentuk asetnya, setidaknya terdapat dua jenis investasi yakni investasi di sector riil dan investasi di sektor non riil. Investasi sector riil adalah sektor yang mengikut sertakan fisik secara langsung. Produk investasi pada sector ini misalnya pada logam mulia dan properti. Sedangkan investasi sektor non riil yakni sector keuangan dan pasar modal, yakni investasi yang asetnya berupa aset non fisik.

Dari pembagian jenis investasi di atas, investasi logam mulia seperti emas merupakan salah satu instrumen investasi yang banyak dilakukan dan menjadi dambaan bagi setiap orang saat ini. Hal tersebut tidak terlepas dari keunggulan yang dimiliki oleh jenis investasi model ini yang menjadikan banyak orang memilihnya dengan beberapa alasan di antaranya adalah stabilitas nilai emas lebih stabil dan tidak terpengaruh turun dengan pergolakan ekonomi yang terjadi (zero inflation effect) (Puji Candra, 20II: I5). Emas merupakan primadona investasi, nilainya yang tidak pernah turun, dianggap sebagai lambang kekuasaan dan kekayaan. Emas juga efektif sebagai sarana melindungi nilai asset dari inflasi dan fluktuasi nilai tukar. Disamping itu, emas juga bentuk investasi yang mudah untuk diuangkan, kapan saja dan dimana saja.

Investasi emas menjadi salah satu jenis investasi yang banyak diminati oleh masyarakat. Banyak lembaga keuangan bank maupun non bank yang menawarkan jasa untuk berinvestasi logam mulia tidak terkecuali dengan PT. Pegadaian Syariah. Salah satu produk yang dimiliki oleh PT. Pegadaian Syariah Babakan, Kota Surabaya adalah tabungan emas. Tabungan emas PT. Pegadaian Syariah merupakan layanan pentipan saldo emas yang memudahkan masyarakat untuk berinvestasi emas. Produk tabungan emas ini memungkinkan nasabah melakukan investasi emas secara mudah, murah, aman, dan terpercaya. Banyak keuntungan yang dihasilkan dalam memilih instrumen investasi Volume. 8/No. 2/Juli 2020 Al-Iqtishod |93 
Pengambilan Keputusan Investasi ...

tabungan emas, karena emas dianggap mampu untuk menaklukan inflasi. Berapapun tingkat inflasi, harga emas akan mengikutinya. Ketika laju inflasi begitu tinggi maka harga emas akan naik lebih tinggi lagi (MohYasin, 2016: 3).

Investasi emas termasuk investasi yang paling aman dan paling menguntungkan diantara semua investasi. Masalahnya, emas merupakan objek investasi yang nilainya cenderung naik, sehingga investasi dalam bentuk emas dapat dikatakan hampir selalu menguntungkan dengan risiko yang relative kecil. Namun dalam berinvestasi emas tentunya profit yang dapat diambil bersifat jangka panjang (NurWahanaFajri, 2017:14).

Investasi emas ini terdapat pada PT. PegadaianSyaraiah Cabang Babakan, Kota Surabaya berupa tabungan emas. Pada mulanya PT. Pegadaian meluncurkan program tabungan emas pada Agustus tahun 2015 (Anggriyani Fauziyah, 2016: 56). Tabungan emas merupakan layanan penjualan dan pembelian emas yang dilakukan oleh PT Pegadaian Syariah. Layanan ini memberikan kemudahan bagi nasabah dalam hal bertransaksi, karena selain mudah, tabungan emas ini cenderung murah. Dalam program nyata bunga emas sifatnya cenderung kepada investasi dan dapat dijadikan tabungan secara berkala. Hal itu dapat dilihat pada data yang ada pada pegadaian bahwa berinvestasi emas dapat dilakukan dengan cara menabung. Sifat dari tabungan emas itu sendiri adalah investasi jangka panjang serta tabungan secara berkala. Investasi jangka panjang ini dihadirkan sesuai dengan program pemerintah yang bertujuan untuk memenuhi kebutuhan serta mengajak kalangan masyarakat menengah kebawah dan generasi $\mathrm{Y}$ untuk berinvestasi.

Dalam programnya, saat ini Pegadaian Syariah sudah mulai membidik Generasi Y(Kementrian Pemberdayaan Perempuan, 20I7: 34) untuk melakukan pembukaan rekening pada tabungan emas PT. Pegadaian Syariah. Hal ini senada dengan yang diucapkan oleh Purnomo Sididari PT. Pegadaian bahwasannya saat ini generasi Y diharapkan untuk mulai meletakan uangnya pada instrumen investasi tabungan emas di Pegadaian Syariah. Namun demikian beberapa diantara generasi Y menganggap bahwa saat ini generasi Y belum sepenuhnya melirik investasi tabungan emas, karena mereka menganggap bahwa menabung emas itu identik ditujukan pada orang tua saja selain itu 
mereka menganggap bahwa keuntungan yang bisa dinikmati relatif lama. Hal ini sesuai dengan karakteristik dari generasi Y, menurutYoris Sebastian yaitu ingin serba cepat, mudah berpindah pekerjaan dalam waktu singkat, kreatif, dinamis, melek teknologi, dekat dengan media sosial dan sebagainya (Yoris Sebastian, 2016:36).

Dengan karakteristik semacam itu, maka PT. Pegadaian mulai membuat strategi pemasaran bagi para generasi $\mathrm{Y}$ dengan cara memberikan literasi kepada generasi $\mathrm{Y}$ dengan cara mendatangi kampus-kampus mereka setiap bulannya. Stategi yang lainnya yakni dengan meluncurkan aplikasi Pegadaian Syariah Digital Service (PSDS). Pada aplikasi tersebut generasi Y dapat secara langsung mendownload pada smartphone mereka masingmasing dan dapat mendaftarkan dengan mudah pembukaan rekening tabungan emas (Ringkang Gumiwang, 2019: I).Tabungan emas ini memfasilitasi pembelian emas mulai dari Rp.8000 sudah dapat memiliki 0,0I gr emas. Dengan harga yang terjangkau, PT. Pegadaian Syariah meyakini jika generasi $\mathrm{Y}$ akan memilih instrumen tabungan emas tersebut.

Dalam rangka memaksimalkan tabungan emas untuk memikat Generasi Y oleh karena itu PT Pegadaian Syariah memiliki strategi 5GS yakni: Grow Core (Tumbuh bersama), Grab New (menangkap peluang baru), Groon Talent (Mengembangkan talent internal), Gen Z Tech (menciptakan teknologi terkini), Great Culture (Membangun budaya yang kuat). Tujuan dari strategi tersebut yakni agar supaya masyarakat mau bergabung dengan PT.Pegadaian Syariah untuk menciptakan keuangan yang sehat terutama yang saat ini dibidik oleh PT Pegadaian Syariah yakni Generasi Y, karena dianggap bahwa GenerasiY ini memiliki kontribusi besar terhadap perekonomian serta Generasi Y ini sudah melakakan investasi. Hal ini dapat dilihat dari perilaku konsumen yang dimiliki oleh Generasi Y. Generasi Y saat ini tidak hanya bersifat konsumtif saja melainkan sudah memikirkan tentang investasi.

\section{B. Kajian Pustaka}

\section{Pengambilan Keputusan}

Volume. 8/No. 2/Juli 2020 Al-Iqtishod | 95 
Pengambilan Keputusan Investasi ...

Irham Fahmi mengemukakan bahwa keputusan adalah sebuah proses yang berawal dari latar belakang masalah hingga kepada terbentuknya kesimpulan atau rekomendasi. Rekomendasi itulah yang selanjutnya dipakai dan dijadikan sebagai pedoman dalam basis pengambilan keputusan. Oleh karena itu begitu besarnya pengaruh yang akan terjadi jika rekomndasi yang dihasilkan tersebut terdapat kekeliruan atau adanya kesalahan-kesalahan tersembunyi karena faktor ketidak hati-hatian dalam melakukan pengkajian masalah (Irham Fahmi, 2016: 2).

Schiffman dan Kanuk mendenifinisikan bahwa suatu keputusan dapat dipilih sebagai suatu tindakan dari dua pilihan alternatif. Seorang konsumen yang hendak melakukan pilihan maka ia harus mempunyai pilihan alternatif (Schiffman, 2010: 65).Seperti contohnya seorang konsumen jika ingin melakukan pemilihan instrumen investasi, maka ia dihadapkan pada beberapa instrumen misalkan emas, saham, dan reksa dana. Dengan demikian, ia harus mengambil keputusan instrumen yang dipilih dari beberapa pilihan instrumen investasi.

Berdasarkan beberapa definisi di atas, maka dapat ditarik kesimpulan bahwa pengambilan keputusan (decision making) merupakan suatu proses pemikiran dari pemilihan alternatif yang akan dihasilkan mengenai prediksi ke depan.

a. Tahap-Tahap Pengambilan Keputusan

I. Mendefinisikan masalah tersebut secara jelas dan gamblang atau mudah dimengerti.

2. Membuat daftar masalah yang akan dimunculkan dan menyususnnya secara prioritas dengan maksud agar adanya sistematika yang lebih terarah dan terkendali.

3. Melakukan identifikasi dari setiap masalah tersebut dengan tujuan untuk lebih memberikan gambaran secara lebih tajam dan terarah secara lebih spesifik.

4. Memetakan setiap masalah tersebut berdasarkan kelompoknya masing-masing yang kemudian selanjutnya dibarengi dengan menggunakan model atau alat uji yang dibutuhkan. 
5. Memastikan kembali bahwa alat uji tersebut yang dipergunakan telah sesuai dengan kaidah yang berlaku pada umumnya.

\section{Strategi}

Strategi secara etimologi berasal dari kata strategic yang artinya kiat, cara, taktik utama. Strategi merupakan sebuah pola dari tujuan, visi, misi, dan kebijakan utama serta sebuah perencanaan untuk dapat mencapai hal tersebut yang dapat dinyatakan untuk mempertegas kewajiban perusahaan sekarang atau nanti dan akan seperti apa perusahaan tersebut di masa mendatang. Strategi merupakan hal penting dalam keberlangsungan hidup suatu perusahaan untuk dapat mencapai sasaran atau tujuan perusahaan yang paling efektif dan efisien, perusahaan dapat menghadapi hambatan yang datang dari dalam dan luar perusahaan. Strategi ialah alat yang gunanya untuk mencapai tujuan. Strategi dalam dunia bisnis sangat diperlukan untuk dapat mencapai visi dan misi yang sudah ada pada perusahaan.

Strategi merupakan suatu hal yang penting dalam mempertahankan suatu bisnis. Keunggulan sebuah perusahaan dalam posisi pasar tergantung dari startegi yang diterapkan di dalam perusahaannya. Dalam menjalankan usahanya strategi menjadi bagian penting yang dijalankan untuk mencapai tujuan meskipun dalam perjalanannya harus berhadapan dengan yang mudah ataupun yang susah (Budi Gautama, 2017: 43). Pendapat dari mamduh bahwa strategi ialah penetapan tujuan jangka panjang yang menjadi dasar bagi suatu organisasi dan pemilihan alternatif tindakan dan alokasi sebuah sumber daya yang diperlukan untuk dapat mencapai tujuan tersebut (Mamduh M, 2003: I36).

Dari beberapa pengertian di atas, maka yang dinamakan strategi yakni serangkaian keputusan dan tindakan mendasar yang dibuat oleh suatu perusahaan untuk mencapai tujuaan dan dapat diimplementasikan oleh seluruh jajaran organisasi atau perusahaan, serta dapat bersaing dengan melihat faktor internal dan eksternal perusahaan. Perusahaan dapat melakukan tindakan yang dapat menjadikan keuntungan baik untuk perusahaan maupun pihak lain yang berada di bawah naungan perusahaan.

Volume. 8/No. 2/Juli 2020 Al-Iqtishod |97 
Pengambilan Keputusan Investasi ...

\section{Metode Penelitian}

Jenis penelitian yang digunakan dalam penelitian ini adalah kualitatif yang bersifat deskrptif. Penelitian kualitatif adalah metode yang berlandasan pada filsafat postpositivisme, yang lebih menekankan pada aspek pemahaman secara mendalam terhadap suatu fenomena. Metode penelitian ini menggunakan teknis analisis mendalam (In-depth analysis), yaitu mengkaji masalah secara kasus perkasus karena metodelogi kualitatif meyakini bahwa sifat suatu masalah akan berbeda dengan sifat dari masalah lainnya. Tujuan dari penelitian ini bukan suatu generalisasi tetapi pemahaman secara mendalam terhadap suatu masalah. Penelitian kualitatif adalah sebagai penelitian yang bermaksud untuk memahami fenomena tentang apa yang di alami oleh subjek penelitian misalnya perilaku, persepsi, motivasi, tindakan, dll., secara holistik, dan dengan cara deskripsi dalam bentuk kata-kata dan bahasa, pada suatu konteks khusus yang alamiah dan dengan memanfaatkan metode alamiah.

\section{Hasil dan Pembahasan}

\section{Strategi Pegadaian Syariah dalam Membidik Generasi Y untuk Investasi Pada Produk Tabungan Emas}

Menjalankan strategi peningkatan jumlah nasabah tabungan emas itu harus dilakukan dengan cara sesuai dengan syariah atau Islam. Dalam meningkatkan jumlah nasabah tabungan emas, banyak strategi yang digunakan oleh Pegadaian Syariah Babakan salah satunya dengan perluasan saluran distribusi. Oleh karena itu, di dalam menyusun rencana peningkatan nasabah, pegadaian syariah ini melakukan pengenalan produk terhadap calon nasabah. Hal ini berguna untuk menentukan terlebih dahulu target atau segmen pasar yang akan dituju untuk dapat dipasarkan produk tabungan emas. Setelah penentuan target tersebut dilakukan maka langkah selanjutnya yang diambil yakni pemilihan pasar sasaran produk kepada calon nasabah potensial diantaranya yakni kepada kaum generasi Y untuk membuka rekening tabungan emas.

Dengan adanya pemilihan sasaran yang memilih generasi $\mathrm{Y}$ untuk membuka rekening tabungan terdapat peningkatan selama tiga tahun terakhir. Peningkatan target 
tersebut menunjukkan bahwa masayarakat makin tertarik dengan produk tabungan emas pegadaian syariah. Pada tahun 2020 pegadaian syariah mentargetkan penjualan emas dapat mencapai angka 5,6 ton dan diantaranya 2,4 ton diperuntukkan untuk tabungan emas. Dengan adanya peningkatan target tersebut, kini pegadaian syariah tidak hanya focus memasarkan produk melalui gerai saja melainkan juga menjalin kerja sama dengan Toko pedia untuk menyediakan fitur jual beli emas secara online. Hal itu dilakukan oleh pegadaian syariah untuk menambah peningkatan jumlah nasabah tabungan emas.

Untuk mencapai peningkatan jumlah nasabah generasi Y, Kepala Pegadaian Syariah Babakan ini mengatakan bahwa pihaknya juga telah melakukan perluasan saluran pemasaran dengan cara mengadakan promo menarik yang ada di outlet. Promo yang dilakukan di outlet-outlet ini biasanya dipasarkan kepada nasabah yang bertransaksi di outlet. Dengan adanya promo ini, dianggap lebih efektif dalam meningkatkan jumlah nasabah tabungan emas.

Strategi yang lain yakni dengan cara datang ke arisan-arisan ibu PKK dan juga masuk ke pasar atau dengan kata lain grebek pasar. Dengan melakukan cara tersebut pegadaian syariah dapat menyebarkan brosur kepada pemilik lapak yang ada di pasar dan juga dapat memberikan sosialisasi atau pengarahan terhadap masyarakat. Hal ini dapat mendorong berkembangnya produk tabungan emas milik Pegadaian Syariah serta dapat meningkatkan jumlah nasabah.

Strategi peningkatan nasabah pada Pegadaian Syariah Cabang Babakan ini juga memanfaatkan teknologi yang saat ini berkembang. Hal ini dapat dilihat dengan banyaknya iklan yang ditawarkan melalui media social dengan sasaran utamanya adalah kaum Generasi Y. Dalam pemasaran yang ada di iklan tersebut biasanya banyak yang berada di media social yakni Instagram. Akun media sosial yang dimiliki oleh pegadaian syariah ini ialah@pegadaian syariah pusat dengan jumlah followersnya mencapai I6 ribu orang. Terdapat berbagai macam promo yang menarik seperti halnya adanya potongan harga tabungan emas hanya dengan memasukkan kode diskon ketika Volume. 8/No. 2/Juli 2020 Al-Iqtishod | 99 
Pengambilan Keputusan Investasi ...

pembelian, adanya bonus berupa cashback, motor, mobil sampai dengan umroh jika ada yang beruntung dalam bertransaksi tabungan emas.

Promo tersebut juga dapat dilakukan pada aplikasi yang dimiliki oleh Pegadaian Syariah Digital Service (PSDS). PSDS merupakan aplikasi yang diluncurkan oleh Pegadaian Syariah yang dapat diakses melalui aplikasi pada smartphone. Layanan pada aplikasi ini dimaksudkan salah satunya untuk menyasar kaum Generasi Y. Semakin berkembangnya zaman maka pegadaian juga harus semakin lincah untuk mengikuti tren zaman Generasi Y. Dengan adanya aplikasi tersebut, Generasi Y antara lain dapat mengecek harga emas, melihat lokasi kantor pegadaian, hingga dapat membeli produk. Di dalam aplikasi Pegadaian Syariah Digital Service terdapat banyak sekali promo yang dilakukan di dalamnya.

Dalam penerapan strateginya, pegadaian menjelaskan cara dan keunggulan yang dimiliki yakni dengan cara menggunakan uang yang ditabungkan kepada Pegadaian Syariah yang kemudian uang tersebut akan dikonversikan kedalam jumlah gram emas. Mutu yang diberikan oleh produk ini meliputi pemberian fasilitas dan kemudahan yang terdapat dalam karakteristik produk.

\section{Pengambilan Keputusan Investasi Produk Tabungan Emas Oleh Generasi Y di Pegadaian Syariah Babakan}

Generasi $Y$ atau yang biasa dikenal dengan generasi milenial ini lahir pada tahun 1980-2000. Generasi ini digambarkan sebagai generasi yang kreatif, memiliki solusi dimana solusi tersebut dapat fokus, sadar sosial, dantim oriented. Generasi Y tumbuh saat memasuki usia pada penerapan dunia digital dengan sumber informasi yang beragam. Pada umumnya Generasi Y ini banyak menggunakan teknologi komunikasi seperti halnya komunikasi instan atau yang biasa disebut dengan email, SMS, chating dan lain-lain. Hal ini disebabkan karena Generasi Y ialah generasi yang adapada era internet booming.

Saat ini, Generasi Y menjadi perbincangan yang hangat pada sector dimanapun. Mulai dari sector keuangan, wisata, makanan, perumahan, transportasi semua pada 
berebut untuk mendapatkan perhatian dari mereka. Hal ini disebabkan karena Generasi Y merupakan generasi yang memiliki kelompok yang sangat besar dan dapat dijadikan target pasar yang sangat potensial untuk berbagai sektor, termasuk salah satunya adalah investasi.

Saat hendak mengambil keputusan untuk berinvestasi tabungan emas maka yang harus dilakukanya mengumpulkan informasi terkait dengan produk yang akan diambil karena setelah informasi dan data yang diperlukan tersebut sudah terkumpul maka dapat dipelajari dengan baik. Seperti halnya tabungan emas Pegadaian Syariah ini, sebelum memutuskan untuk berinvestasi ada baiknya mencari tahu terlebih dahulu produk tersebut dan kemudian jika produk tersebut dinilai cocok maka kita dapat menjadikannya sebagai instrument investasi yang tepat.

Yang kedua yakni perancangan. Pada tahap ini Generasi Y yang hendak melakukan investasi tabungan emas maka mengembangkan dan menganalisis kemungkinan yang terjadi seperti halnya saat ini. Pada saat ini di era pandemi yang terjadi akibat covid 19 ini para generasi Y berbondong-bondong meletakkan uang mereka kepada instrument investasi tabungan emas. Hal ini disebabkan karena ketika IHSG (Indeks Harga Saham Gabungan) dan nilai tukar rupiah terhadap dolar AS ini turun, jusrtu harga emas semakin naik, maka Generasi Y mengambil tindakan yang sebelumnya sudah dirancang dan di anlisis secara matang untuk meletakkan uang mereka kepada tabungan emas.

Ketiga adalah kegiatan pemilihan. Kegiatan pemilihan ini merupakan keputusan pembelian. Pada tahap evaluasi ini konsumen membentuk preferensi terhadap merekmerek yang terdapat pada perangkat pilihan. Konsumen membentuk tujuan membeli untuk merek dan produk yang disukai. Namun demikian terdapat dua faktor yang mempengaruhi tujuan pembelian dan keputusan pembelian. Faktor pertama yakni sikap orang lain, sejauh mana sikap orang lain akan mengurangi alternative pilihan seseorang tergantung karena dua hal: (I) Intensitas sikap negatif orang lain terhadap alternative pilihan yang dipilih oleh konsumen, (2) motivasi konsumen untuk menuruti orang Volume. 8/No. 2/Juli 2020 Al-Iqtishod | IOI 
Pengambilan Keputusan Investasi ...

tersebut. Semakin tinggi intensitas sikap negative seseorang maka akan semakin dekat hubungan dengan konsumen dimana akan meningkatkan dan menyesuaikan tujuan pembeliannya. Pada tahap ini generasi Y dituntut cakap dan bijak dalam menentukan instrument investasi untuk menghasilkan keuntungan di masa mendatang sehingga uang yang diletakkan pada instrumen investasi tersebut dapat membawa keuntungan yang maksimal.

Keempat ialah kegiatan peninjauan dan evaluasi. Pada tahap ini setelah Generasi Y meletakkan pilihan investasinya maka yang harus dilakukan yakni dengan mengevaluasi pilihan tersebut apakah sudah sesuai dengan yang semestinya sehingga keuntungan yang nanti dirasakan jauh lebih maksimal dan tidak menimbulkan kerugian. Pada tahap ini berarti merupakan perilaku pasca pembelian. Sesudah memtuskan untuk membeli produk investasi tabungan emas yang dilakukan oleh Generasi Y, maka ditemukan adanya tingkat kepuasan atau ketidakpuasan. Generasi Y tersebut juga akan terlibat dalam tindakan sesudah pembelian dan penggunaan produkinvestasi tabungan emas yang menarik minat pemasar (PegadaianSyaraiah). PekerjaanPemasar/ Pegadaian Syariah Cabang Babakan tidak akan berakhir pada saat suatu produkinvestasi mereka dibeli melainkan akan terus berlangsung hingga sampai periode sesudah pembelian.

\section{E. Simpulan}

Dalam upaya peningkatan jumlah nasabah, strategi yang dilakukan oleh Pegadaian Syariah Cabang Babakan, Surabaya ini dengan cara melakukan pengenalan produk kepada para nasabah khususnya kepada nasabah Generasi Y. Pegadaian memberikan literasi tentang produk tabungan emas kepada semua kalangan dimulai dari anak sekolah pendidikan usia dini sampai kepada orang tua. Dalam strateginya, pegadaian juga memanfaatkan media elektronik berupa surat kabar dan juga media sosial. Beragam promo diberikan di media sosial Instagram dan juga Facebook milik pegadaian. Promo yang diberikan berupa diskon atau cashback serta biaya penghapusan administrasi selama satu 
tahun. Selain dari pada itu, pegadaian juga memberikan strategi berupa keuntungan yang menabung emas akan mendapatkan hadiah seperti umroh dan kendaraan. Strategi yang lain yakni dengan dating ke event-event kampus, pasar, dan juga arisan. Hal ini bertujuan untuk mengenalkan dan memberikan literasi tentang produk yang dimiliki oleh pegadaian khususnya tabungan emas. Dengan memberikan literasi ini, yang diharapkan oleh Pegadaian Syariah yakni adanya peningkatan jumlah nasabah tabungan emas.

Dalam pengambilan keputusan yang diambil oleh Generasi Y untuk menabung emas terdapat beberapa faktor yang mempengaruhi. Faktor yang mempengerahui yakni kondisi ekonomi, sosial, dan psikologis. Pada kondisi ekonomi Generasi Y terbagi menjadi dua yakni generasi Y yang sudah sadar akan pentingnya investasi untuk kehidupan mereka dan juga Generasi Y yang masih belum melek tentang investasi. Generasi Y yang sudah melek investasi disini adalah generasi $\mathrm{Y}$ yang sudah mulai mengalokasikan uangnya untuk berinvestasi pada instrumen investasi salah satunya investasi tabungan emas. Generasi Y yang memilih tabungan emas ini dikarenakan tabungan emas ini murah, aman dan mudah dimana hal tersebut sesuai dengan yang diinginkan oleh Generasi Y. Sedangkan Generasi Y yang belum sadar akan pentingnya investasi yakni Generasi Y yang mementingkan gaya hidupnya saja dan cenderung konsumtif. Konsumtif disini yakni dengan pembelian barangbarang branded, pembaruan gadget, serta belanja online dan nongkrong pada coffee shop.

Yang kedua yakni sosial. Dengan adanya kelompok referensi yang merekomendasikan produk tabungan emas kepada Generasi Y. Yang ketiga yakni adanya factor psikologis dimana factor tesebut sangatlah mempengarui terhadap pengambilan keputusan keuangan. Karena keberadaannya diawali dari psikologis manusia sebagai bawaan kodrat manusia yakni dorongan ingin tahu dari kehendak dan kemauan termasuk dalam berinvestasi.

\section{F. Daftar Pustaka}

\section{Buku}

Assael, Henry. Consumer Behaviour and Marketing Action, Newyork: Learning, 2001

Volume. 8/No. 2/Juli 2020 Al-Iqtishod | I03 
Pengambilan Keputusan Investasi ...

Badan Pusat Statistik, Statistik Gender Tematik: Profil Generasi Milenial Indonesia,

(Tk: Kementrian Pemberdayaan Perempuan dan Perlindungan Anak, 2018)

Halim, Abdul. Analisis Investasi, Jakarta: Salemba Empat, 2005

Irham Fahmi, Manajemen Pengambilan KeputusanTeori dan Aplikasi, Bandung: Alfabeta, 2016

Mamduh M. Hanafi, Manajemen, (Yogyakarta: Unit Penerbit, 2003)

Mohammad Yasin dan Sri Ethichawati, Ekonomi untuk Sekolah Menengah Pertama, Jakarta: Rajawali Pers, 2016

Nugroho Setiadi, Perilaku Konsumen: Perspektif Kontemporer Pada Motif, Tujuan, dan Keinginan Konsumen, Jakarta: Prenada media Grup, 2015

Puji Chandra, 8 Kunci Sukses Investasi Emas, Jakarta: Ruzz Media, 20 I I

\section{Artikel Jurnal Versi Online}

Adeng SeptiIrawan, https://jatim.tribunnews.com/amp/lembaga-riset-ipolindonesia/, diakses tanggal 02 Juni 2020.

Anggriani Fauziyah, "Peluang Investasi Emas Jangka Panjang Melalui Produk Pembiayaan BSM Cicil Emas: Studi Pada Bank Syariah Mandiri KC. Purwokerto,” Islamadina; Jurnal Pemikiran Islam, Vol XVI, No. OI, (Maret, 2016)

Assael, Henry. Consumer Behaviour and Marketing Action, Newyork: Learning, 2001

Budi Gautama Siregar, "Strategi Bersaing Dalam Menigkatkan Jumlah Nasabah PT. Bank Sumut Cabang Syariah Padang Sidimpuan,” Jurnal Kajian Ilmu Keislaman Vol. 03, No I (Juli, 2017)

Ferrika Sari, Tabungan Emas, https://keuangan.kontan.co.id, diakses I4 Juni 2020.

Kulkanya Napompech, "Factors Influecing Gold Consumption for Saving and Investment by People in The Bangkok Metropolitan Area," International Journal of Arts and Science. Vol 3 No. 7 (Juli, 20I0)

I04 | Al-Iqtishod Volume. 8/No. 2/Juli 2020 
Martin Surya danYunita Anwar Mulyadi, "Gold Versus Stock Investment: An Econometric Analysis, International Journal of Development and Sustainability,” Vol. I No. I (Desember, 2012)

Pegadaian, “Apa itu Tabungan Emas”, www.pegadaian.co.id/produk/tabunganemas: diakses tanggal IO Desember 2019

Ringkang Gumiwang, "Pegadaian Hingga Bank: Trik Menjaring Nasabah Milenial," www.google.com/amp/s/amp/tirto.id; diaksestanggal 3I Desember 2019

\section{Skripsi, Tesis, dan Disertasi}

Nur Wahana Fajri, "Analisis Prinsip Ekonomi Islam Terhadap Operasional Produk Investasi Emas Pada Pegadaian Syariah: Studi Pegadaian Syariah Cabang Hasanudin Gowa” Tesis -- UIN AlaudinMakasar, 2017 